
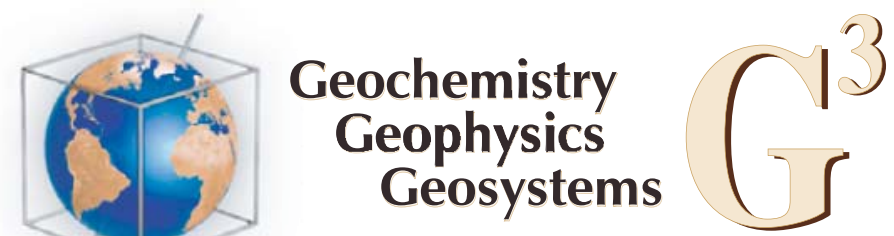

Published by AGU and the Geochemical Society

\title{
Tectonic and magmatic controls on hydrothermal activity in the Woodlark Basin
}

\section{T. E. Laurila}

Department of Earth Sciences, University of Ottawa, Marion Hall, Ottawa, Ontario K1N 6N5, Canada(tea.laurila@uottawa.ca)

\section{S. Petersen and C. W. Devey}

GEOMAR, Helmholtz Centre for Ocean Research Kiel, Wischhofstrasse 1-3, DE-24148 Kiel, Germany

\section{E. T. Baker}

PMEL, NOAA, 7600 Sand Point Way NE, Building 3, Seattle, Washington 98115-0070, USA

\section{N. Augustin}

GEOMAR, Helmboltz Centre for Ocean Research Kiel, Wischhofstrasse 1-3, DE-24148 Kiel, Germany

\author{
M. D. Hannington \\ Department of Earth Sciences, University of Ottawa, Marion Hall, Ottawa, Ontario K1N 6N5, \\ Canada
}

[1] The Woodlark Basin is one of the rare places on earth where the transition from continental breakup to seafloor spreading can be observed. The potential juxtaposition of continental rocks, a large magmatic heat source, crustal-scale faulting, and hydrothermal circulation has made the Woodlark Basin a prime target for seafloor mineral exploration. However, over the past 20 years, only two locations of active hydrothermalism had been found. In 2009 we surveyed $435 \mathrm{~km}$ of the spreading axis for the presence of hydrothermal plumes. Only one additional plume was found, bringing the total number of plumes known over $520 \mathrm{~km}$ of ridge axis to only 3 , much less than at ridges with similar spreading rates globally. Particularly the western half of the basin ( $280 \mathrm{~km}$ of axis) is apparently devoid of high temperature plumes despite having thick crust and a presumably high magmatic budget. This paucity of hydrothermal activity may be related to the peculiar tectonic setting at Woodlark, where repeated ridge jumps and a re-location of the rotation pole both lead to axial magmatism being more widely distributed than at many other, more mature and stable midocean ridges. These factors could inhibit the development of both a stable magmatic heat source and the deeply penetrating faults needed to create long-lived hydrothermal systems. We conclude that large seafloor massive sulfide deposits, potential targets for seafloor mineral exploration, will probably not be present along the spreading axis of the Woodlark Basin, especially in its younger, western portion.

Components: 7900 words, 6 figures, 1 table.

Keywords: Franklin Seamount; Woodlark; hydrothermal plume; neovolcanic; spreading.

Index Terms: 1032 Geochemistry: Mid-oceanic ridge processes $(3614,8416) ; 1034$ Geochemistry: Hydrothermal systems (0450, 3017, 3616, 4832, 8135, 8424).

Received 22 May 2012; Revised 31 July 2012; Accepted 14 August 2012; Published 13 September 2012. 
Laurila, T. E., S. Petersen, C. W. Devey, E. T. Baker, N. Augustin, and M. D. Hannington (2012), Tectonic and magmatic controls on hydrothermal activity in the Woodlark Basin, Geochem. Geophys. Geosyst., 13, Q09006, doi:10.1029/ 2012 GC004247.

\section{Introduction}

[2] The Woodlark Basin is one of the few places on the Earth where active seafloor propagation into continental crust can be studied. The wedge-shaped Basin contains an approximately E-W oriented active spreading axis divided into five spreading segments, numbered 1 to 5 from West to East by Goodliffe et al. [1997]. The regional tectonic setting, in the convergence zone between the Pacific and Australian plates, is complex, with small plates colliding, breaking apart and shearing against each other (Figure 1). Two locations of present-day hydrothermal activity (Figures 1 and 2) were previously known in the Woodlark Basin, namely Franklin Seamount on Segment 1 [Lisitzin et al., 1991; Binns et al., 1993] and an unnamed plume site on Segment 5 (M. Leybourne et al., Evidence for hydrothermal activity in the Woodlark Basin, an arc-influenced oceanic spreading center, manuscript in preparation, 2012). During cruise SO-203 in late 2009, $435 \mathrm{~km}$ of Woodlark Segments 1 to 4 and their immediate surroundings were mapped, sampled and prospected for the presence of hydrothermal plumes. In this paper we examine the extent of present-day hydrothermal activity detected on-axis and compare it with observations at other spreading ridges globally. The low incidence of hydrothermal activity found is explained as a result of the particular tectonic situation of the Woodlark Basin.

\subsection{Tectonic Setting}

[3] Extension and thinning of the Papuan continental lithosphere started around $8.4 \mathrm{Ma}$ [Weissel et al., 1982; Taylor et al., 1995; Taylor and Huchon, 2002]. By about $6 \mathrm{Ma}$, continued rifting of the former eastern extension of the Papuan Peninsula (which now forms the Woodlark and Pocklington Rises, Figure 1) led to the initiation of east-west oriented spreading and the formation of seafloor in the young Woodlark Basin near $\sim 157^{\circ} \mathrm{E}$. It seems likely that spreading began even further east, near $159^{\circ} \mathrm{E}$ (A. Goodliffe, personal communication, 2012), but as the older parts of the basin have already been subducted the evidence for this is missing. The transition from rifting to spreading jumped steadily westward, stepping across the Simbo Transform (and so initiating spreading on Segment 5) at $3.6 \mathrm{Ma}$ and crossing the Moresby Transform (initiating Segment
2) at ca. 2 Ma. By approximately $0.7 \mathrm{Ma}$, oceanic spreading had begun as far west as $151^{\circ} 70^{\prime} \mathrm{E}$, the current westerly limit of the creation of new oceanic crust [Taylor et al., 1999].

[4] The westward movement of spreading in the Woodlark Basin occurred by consecutive jumps to new nucleation centers. Initiation of new spreading segments took place at the weakest part of the previously rifted continental crust [Goodliffe et al., 1997; Taylor et al., 1999]. The newly initiated rift axis then propagated east and west, splitting the continental lithosphere at least until the eastern tip of the new segment began to overlap with the preexisting segments further east [Taylor et al., 1999]. The change from continental rifting to spreading appears to generally have been accompanied by a sharp change in crustal structure. In particular, there is generally little evidence for extensive intrusion of mafic magmas into the upper continental crust prior to the onset of spreading [Ferris et al., 2006] although in the case of Segment 2 Taylor et al. [1999] attributed some curvilinear magnetic anomalies to structurally controlled intrusion into stretched continental crust.

[5] The newly formed crust shows some major differences between the eastern and western halves of the basin. Martinez et al. [1999] showed that seafloor formed at Segments 1 and 2 is significantly shallower than that formed at Segments 3 and 4. Also the form of the axis itself differs, with Segments 3 and 4 having a well developed axial graben whereas Segments 1 and 2, despite having a slower spreading rate, form either axial highs or have only a subdued morphological expression. The western segments are separated from each other by second-order ("over-lapper") discontinuities, whereas Segments 3 and 4 are bounded by first order transform faults.

[6] The location of the Euler pole of opening for the Woodlark Basin (at $\left.12^{\circ} \mathrm{S} / 144^{\circ} \mathrm{E}\right)$ is presently very close to, and west of, the western tip of the present-day rifting (Figure 1). As a result, spreading rates vary significantly across the basin, from $67 \mathrm{~mm} / \mathrm{yr}$ near the Simbo Transform Fault (the eastern end of the present Woodlark spreading axis) to $36 \mathrm{~mm} / \mathrm{yr}$ near Moresby Seamount, the present westerly extent of spreading (rates from Taylor et al. [1995, Figure 1]). These are full rates and comparable to 


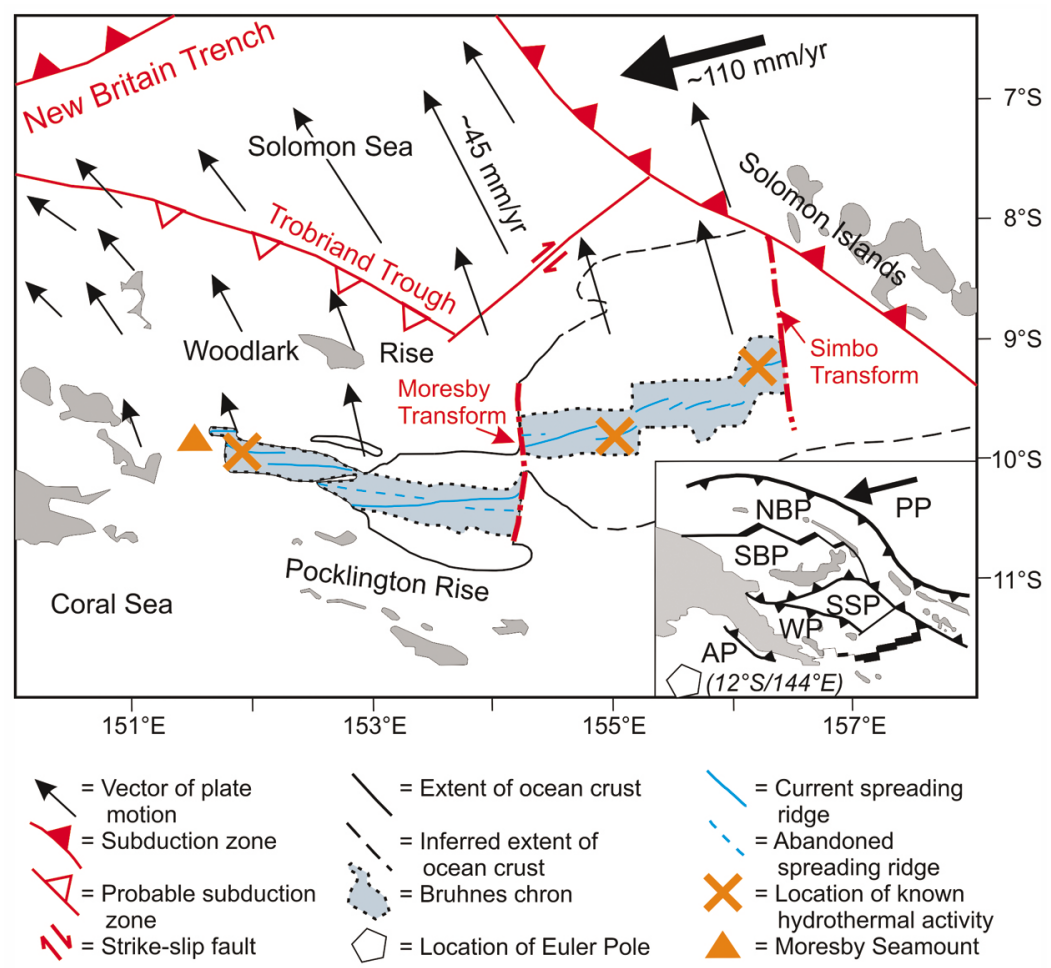

Figure 1. The tectonic setting of the Woodlark Basin. The main figure shows the location of the zone of normally magnetized seafloor created by the present-day (blue continuous line) or abandoned (blue dashed line) spreading axes. Arrows show the directions of plate motion relative to a fixed Australian plate. The location of known hydrothermal vent sites (crosses) and Moresby Seamount (triangle) are also marked. Inset shows the regional overview, with numerous small plates $(\mathrm{WP}=$ Woodlark Plate, $\mathrm{S} / \mathrm{NBP}=$ South/North Bismarck Plate, $\mathrm{SSP}=$ Solomon Sea Plate $)$ sandwiched between the Pacific (PP) and Australian Plate (AP). Also marked is the present location of the WP/AP Euler Pole of rotation. Modified after Little et al. [2007].

those which can be calculated using the Euler poles given by Taylor et al. [1999] although somewhat larger than the rates $(29.7 \mathrm{~mm} / \mathrm{yr}$ and $44 \mathrm{~mm} / \mathrm{yr})$ that would be given based on the present-day pole derived from GPS motion vectors [Tregoning et al., 1998]. The proximity of the Euler Pole means that transform offsets of the axis are strongly curved and small changes in the pole location can lead to large changes in the orientation of orthogonally spreading segments.

[7] The position of the Euler Pole of opening changed at approximately $0.52 \mathrm{Ma}$ and the orientation of the ridge axis shifted more than $20^{\circ}$ anticlockwise within the last $\sim 80 \mathrm{ka}$ [Goodliffe et al., 1997]. The response to this change was also different between the western and eastern part of the Basin. The axes of Segments 1 and 2 re-orientated wholesale whereas the reorientation led both to Segments 3 and 4 producing a suite of en echelon second-order segments within the pre-existing axial graben and to extension beginning across the fracture zones. All of these differences between the western and eastern part of the Woodlark Basin have been attributed by Martínez et al. [1999] to variations in the response of the asthenosphere to continental splitting, with the thicker continental material adjacent to Segments 1 and 2 leading to secondary mantle convection beneath this area and hence increased magma production, thicker crust and shallower water depths.

\section{Sampling}

[8] Sampling of the Woodlark spreading axis for petrological studies was carried out using dredge, TV-grab and volcanic rock corer along the segments 1 to $4 \mathrm{C}$ (Figure 2). Whenever seafloor topography made a deployment possible, Miniature Autonomous Plume Recorders (MAPR) equipped with temperature, pressure, light-backscattering, and oxidation-reduction potential (ORP, aka Eh) sensors, were attached to the wire, allowing the water column to be 


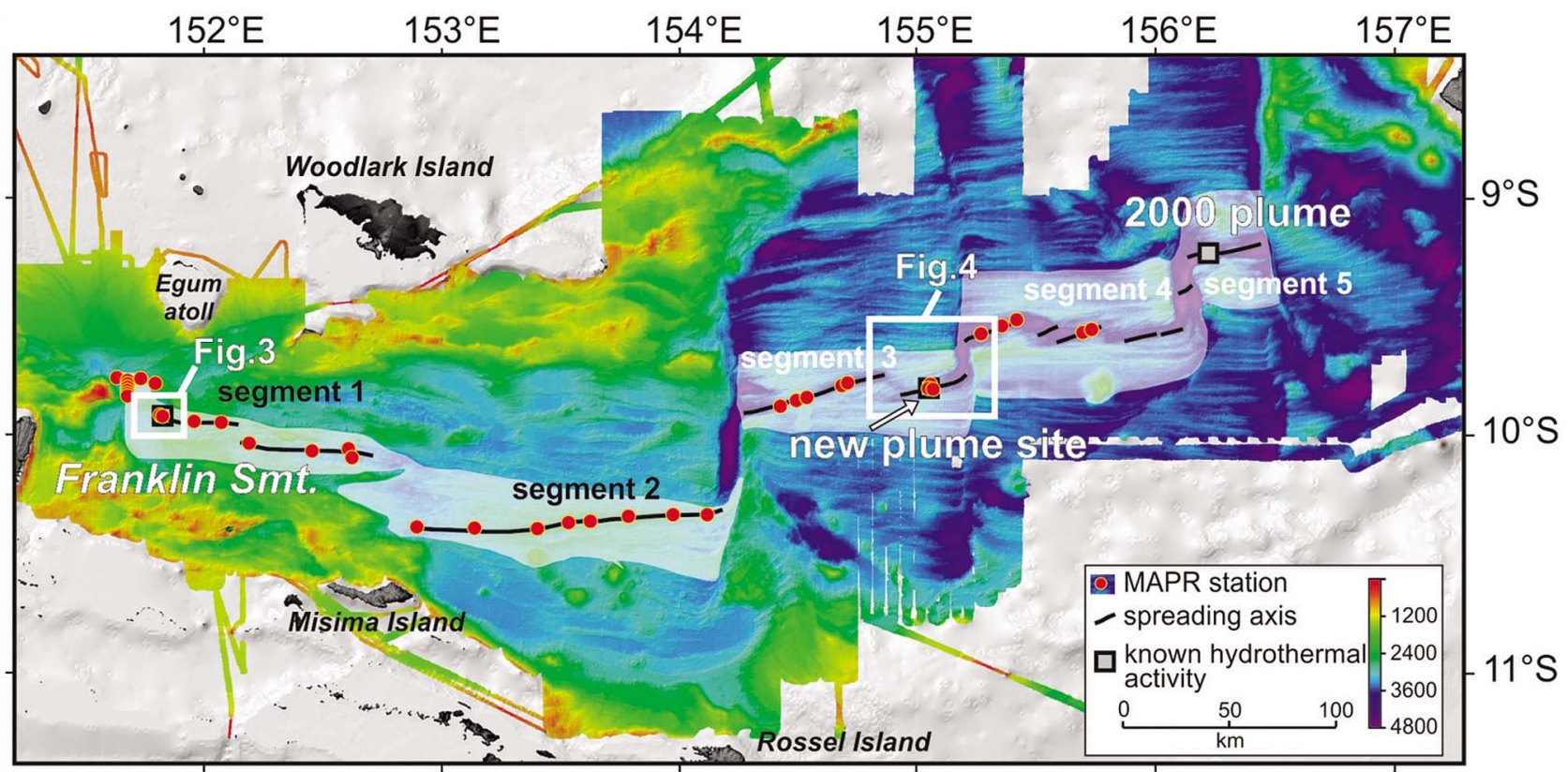

Figure 2. Bathymetric map of the Woodlark Basin based on data from Taylor et al. [1995] and Kington and Goodliffe [2008]. The locations of the present-day spreading segments and sampling sites along them are marked. The light shading shows the area of normally magnetized seafloor (Bruhnes Chron). Note that the spreading axes are not located symmetrically within the Bruhnes regions. The location of active vent sites and areas shown in detail in other figures are marked.

concurrently surveyed for signs of hydrothermal activity [e.g., Baker et al., 2010]. The voltage output of the light-backscattering sensor is equivalent to nephelometric turbidity units (NTU) [American Public Health Association, 1985]; $\triangle$ NTU is the value above ambient non-plume water. Oxidationreduction potential is highly sensitive to short-lived reduced chemicals in hydrothermal plumes, such as $\mathrm{Fe}^{2+}$ and $\mathrm{H}_{2} \mathrm{~S}$ [Walker et al., 2008]. Instead of using absolute values of the ORP sensor (the potential E, measured in $\mathrm{mV}$ ), which can vary because of instrumental drift and hysteresis, we used the time derivative, $\mathrm{dE} / \mathrm{dt}$, to identify the precise location of anomalies by their rapidly changing ORP. Because the oxidation-reduction potential decreases when it encounters reduced substances, the anomalies are negative. A data-recording interval of $5 \mathrm{~s}$ was used for all deployments.

[9] MAPRs were deployed at a total of 38 stations (median spacing $15.7 \mathrm{~km}$ on Segments 1 and 2 and median spacing $4.8 \mathrm{~km}$ on Segments 3 and 4) along the spreading axis (Figure 2 and Table 1). For volcanic rock corer stations and during the acquisition of the sound velocity profile using a CTDpackage, a single MAPR was attached to the cable $50 \mathrm{~m}$ above the instrument so the MAPR reached a depth of $\sim 50 \mathrm{~m}$ above the seafloor. During dredging, the MAPR was attached 300-400 $\mathrm{m}$ above the dredge bag to prevent any damage, thus it reached variable depths (see Table 1). At one location, tow-yo operations with five MAPRs were conducted by winching the dredge wire in and out at a speed of $1 \mathrm{~m} / \mathrm{s}$ as the ship steamed ahead at 1 knot.

[10] When sampling with the dredge or volcanic corer, we targeted the neovolcanic zone as previously defined by magnetic anomalies and shallow-towed side scan data [Taylor et al., 1999] (Figure 2). During shipboard activities we confirmed the position of the neovolcanic zone based on strong backscatter signals from the ship's own EM-120 Simrad multibeam system. The collection of fresh volcanic rocks but no sediment in the high backscatter region was taken as a strong indicator of a successful neovolcanic zone dredge (see Table 1 for details of samples recovered at each station).

[11] The spacing of MAPR deployments along Segments 1 and 2, which are characterized by an axial high or very shallow axial valley, was typically (median) $\sim 15 \mathrm{~km}$ with the largest spacing being $29 \mathrm{~km}$ (Figure 2). Typical plume lengths on slow and intermediate rate ridges [e.g., Baker et al., 1995] are $\sim 10 \mathrm{~km}$, so gaps in our survey of Segments 1 and 2 are large enough for a neutrally buoyant plume to have gone undetected. The density of MAPR deployments along Segments 3 and 4 was much greater (median $4.8 \mathrm{~km}$, longest section of axis not 
Table 1. Details of MAPR Deployments in the Woodlark Basin ${ }^{\mathrm{a}}$

\begin{tabular}{|c|c|c|c|c|c|c|}
\hline Stat & Date & Location, Instrument & GPS Coordinates & Water Depth & MAPR Depth & Recovery \\
\hline 02 & 29.10 .09 & segment1B, CTD & $09^{\circ} 56.31^{\prime} \mathrm{S}, 151^{\circ} 58.24^{\prime} \mathrm{E}$ & $2699 \mathrm{~m}$ & $153 \mathrm{~m}$ & - \\
\hline 08 & 31.10 .09 & Cheshire Smt. VSR & $09^{\circ} 46.72^{\prime} \mathrm{S}, 151^{\circ} 48.68^{\prime} \mathrm{E}$ & $1686 \mathrm{~m}$ & $50 \mathrm{~m}$ & FG \\
\hline 16 & 01.11 .09 & SE rim of Franklin., VSR & $09^{\circ} 54.69^{\prime} \mathrm{S}, 151^{\circ} 49.82^{\prime} \mathrm{E}$ & $2149 \mathrm{~m}$ & $50 \mathrm{~m}$ & FG \\
\hline 17 & 01.11 .09 & ridge SE of Franklin. VSR & $09^{\circ} 55.00^{\prime} \mathrm{S}, 151^{\circ} 50.33^{\prime} \mathrm{E}$ & $2310 \mathrm{~m}$ & $50 \mathrm{~m}$ & FG \\
\hline 18 & 01.11 .09 & ridge SE of Franklin VSR & $09^{\circ} 55.00^{\prime} \mathrm{S}, 151^{\circ} 50.34^{\prime} \mathrm{E}$ & $2370 \mathrm{~m}$ & $50 \mathrm{~m}$ & FG \\
\hline 50 & 06.11 .09 & $\mathrm{~W}$ end of seg. $1 \mathrm{~A}, \mathrm{VSR}$ & $09^{\circ} 46.00^{\prime} \mathrm{S}, 151^{\circ} 41.39^{\prime} \mathrm{E}$ & $3195 \mathrm{~m}$ & $50 \mathrm{~m}$ & FG \\
\hline 51 & 06.11 .09 & Wend of seg. 1A, VSR & $09^{\circ} 46.91^{\prime} \mathrm{S}, 151^{\circ} 41.39^{\prime} \mathrm{E}$ & $3209 \mathrm{~m}$ & $50 \mathrm{~m}$ & $\mathrm{AG}$ \\
\hline 52 & 06.11 .09 & $\mathrm{~W}$ end of seg. $1 \mathrm{~A}$, VSR & $09^{\circ} 47.80^{\prime} \mathrm{S}, 151^{\circ} 41.40^{\prime} \mathrm{E}$ & $3201 \mathrm{~m}$ & $50 \mathrm{~m}$ & FG \\
\hline 53 & 06.11 .09 & $\mathrm{~W}$ end of seg. $1 \mathrm{~A}$, VSR & $09^{\circ} 48.68^{\prime} \mathrm{S}, 151^{\circ} 41.38^{\prime} \mathrm{E}$ & $3232 \mathrm{~m}$ & $50 \mathrm{~m}$ & - \\
\hline 54 & 06.11 .09 & $\mathrm{~W}$ end of seg. $1 \mathrm{~A}$, VSR & $09^{\circ} 49.31^{\prime} \mathrm{S}, 151^{\circ} 41.39^{\prime} \mathrm{E}$ & $3235 \mathrm{~m}$ & $50 \mathrm{~m}$ & FG \\
\hline 73 & 10.11 .09 & Seg. $1 \mathrm{~B}, \mathrm{DR}$ & $09^{\circ} 56.61^{\prime} \mathrm{S}, 152^{\circ} 04.99^{\prime} \mathrm{E}$ & $2675 \mathrm{~m}$ & $171 \mathrm{~m}$ & FG \\
\hline 80 & 12.11 .09 & flat part of seg $1 C, D R$ & $10^{\circ} 01.69^{\prime} \mathrm{S}, 152^{\circ} 11.99^{\prime} \mathrm{E}$ & $2768 \mathrm{~m}$ & $99 \mathrm{~m}$ & - \\
\hline 83 & 12.11 .09 & Seg. $1 C$, DR & $10^{\circ} 03.80^{\prime} \mathrm{S}, 152^{\circ} 27.69^{\prime} \mathrm{E}$ & $2926 \mathrm{~m}$ & $115 \mathrm{~m}$ & FG \\
\hline 87 & 13.11 .09 & $\mathrm{~S}$ of axis of seg. $1 \mathrm{C}, \mathrm{DR}$ & $10^{\circ} 05.49^{\prime} \mathrm{S}, 152^{\circ} 37.76^{\prime} \mathrm{E}$ & $3381 \mathrm{~m}$ & $152 \mathrm{~m}$ & FG \\
\hline 88 & 13.11 .09 & crater $\mathrm{N}$ of axis of $1 \mathrm{C}, \mathrm{DR}$ & $10^{\circ} 03.19^{\prime} \mathrm{S}, 152^{\circ} 36.85^{\prime} \mathrm{E}$ & $2950 \mathrm{~m}$ & $169 \mathrm{~m}$ & FG \\
\hline 107 & 18.11 .09 & SE of Moresby Smt., VSR & $09^{\circ} 49.77^{\prime} \mathrm{S}, 151^{\circ} 41.20^{\prime} \mathrm{E}$ & $3232 \mathrm{~m}$ & $50 \mathrm{~m}$ & FG \\
\hline 108 & 18.11 .09 & NE of Moresby Smt., VSR & $09^{\circ} 45.39^{\prime} \mathrm{S}, 151^{\circ} 38.70^{\prime} \mathrm{E}$ & $3094 \mathrm{~m}$ & $50 \mathrm{~m}$ & FG \\
\hline \multirow[t]{2}{*}{109} & 18.11 .09 & ENE of Moresby Smt., VSR & $09^{\circ} 45.65^{\prime} \mathrm{S}, 151^{\circ} 44.75^{\prime} \mathrm{E}$ & $2871 \mathrm{~m}$ & $50 \mathrm{~m}$ & FG \\
\hline & & & Segment 2 & & & \\
\hline 93 & 16.11 .09 & segment 2 , DR & $10^{\circ} 22.90^{\prime} \mathrm{S}, 152^{\circ} 54.00^{\prime} \mathrm{E}$ & $3293 \mathrm{~m}$ & $215 \mathrm{~m} \mathrm{~A}$ & $\mathrm{AG}$ \\
\hline 95 & 16.11 .09 & segment 2 , DR & $10^{\circ} 23.20^{\prime} \mathrm{S}, 153^{\circ} 08.61^{\prime} \mathrm{E}$ & $3080 \mathrm{~m}$ & $197 \mathrm{~m}$ & FG \\
\hline 97 & 17.11 .09 & segment $2, \mathrm{DR}$ & $10^{\circ} 23.32^{\prime} \mathrm{S}, 153^{\circ} 24.42^{\prime} \mathrm{E}$ & $2695 \mathrm{~m}$ & $118 \mathrm{~m}$ & FG \\
\hline 115 & 20.11 .09 & segment $2, \mathrm{DR}$ & $10^{\circ} 21.70^{\prime} \mathrm{S}, 153^{\circ} 32.30^{\prime} \mathrm{E}$ & $2706 \mathrm{~m}$ & $224 \mathrm{~m}$ & FG \\
\hline 116 & 20.11 .09 & segment $2, \mathrm{DR}$ & $10^{\circ} 21.40^{\prime} \mathrm{S}, 153^{\circ} 37.82^{\prime} \mathrm{E}$ & $2619 \mathrm{~m}$ & $140 \mathrm{~m}$ & FG \\
\hline 118 & 20.11 .09 & segment $2, \mathrm{DR}$ & $10^{\circ} 20.20^{\prime} \mathrm{S}, 153^{\circ} 47.20^{\prime} \mathrm{E}$ & $2666 \mathrm{~m}$ & $256 \mathrm{~m} \mathrm{~B}$ & FG \\
\hline 119 & 20.11 .09 & segment $2, \mathrm{DR}$ & $10^{\circ} 19.81^{\prime} \mathrm{S}, 153^{\circ} 58.52^{\prime} \mathrm{E}$ & $2832 \mathrm{~m}$ & $186 \mathrm{~m}$ & FG \\
\hline \multirow[t]{2}{*}{124} & 21.11 .09 & Seg. 2, E end near TF, VSR & $10^{\circ} 19.70^{\prime} \mathrm{S}, 154^{\circ} 07.00^{\prime} \mathrm{E}$ & $2852 \mathrm{~m}$ & $20 \mathrm{~m}$ & FG \\
\hline & & & Segment 3 & & & \\
\hline 127 & 22.11 .09 & segment $3 \mathrm{~A}, \mathrm{DR}$ & $09^{\circ} 52.41^{\prime} \mathrm{S}, 154^{\circ} 25.41^{\prime} \mathrm{E}$ & $3455 \mathrm{~m}$ & $190 \mathrm{~m}$ & FG \\
\hline 128 & 22.11 .09 & segment $3 \mathrm{~A}, \mathrm{DR}$ & $09^{\circ} 51.00^{\prime} \mathrm{S}, 154^{\circ} 29.40^{\prime} \mathrm{E}$ & $3598 \mathrm{~m}$ & $126 \mathrm{~m}$ & FG \\
\hline 129 & 22.11 .09 & segment $3 \mathrm{~A}, \mathrm{DR}$ & $09^{\circ} 50.30^{\prime} \mathrm{S}, 154^{\circ} 32.20^{\prime} \mathrm{E}$ & $3575 \mathrm{~m}$ & $155 \mathrm{~m}$ & FG \\
\hline 130 & 22.11 .09 & segment $3 \mathrm{~A}, \mathrm{DR}$ & $09^{\circ} 47.41^{\prime} \mathrm{S}, 154^{\circ} 41.00^{\prime} \mathrm{E}$ & $3769 \mathrm{~m}$ & $187 \mathrm{~m}$ & FG \\
\hline 131 & 22.11 .09 & segment $3 \mathrm{~A}, \mathrm{DR}$ & $09^{\circ} 46.60^{\prime} \mathrm{S}, 154^{\circ} 42.49^{\prime} \mathrm{E}$ & $3883 \mathrm{~m}$ & $181 \mathrm{~m}$ & FG \\
\hline 137 & 23.11 .09 & segment $3 \mathrm{~B}$, DR & $09^{\circ} 47.51^{\prime} \mathrm{S}, 155^{\circ} 03.60^{\prime} \mathrm{E}$ & $3440 \mathrm{~m}$ & $302 \mathrm{~m} \mathrm{~B}$ & FG \\
\hline 141 & 24.11 .09 & $\mathrm{E}$ end of segment $3 \mathrm{~B}, \mathrm{~T}-\mathrm{Y}$ & $09^{\circ} 48.12^{\prime} \mathrm{S}, 155^{\circ} 01.97^{\prime} \mathrm{E}$ & $3420 \mathrm{~m}$ & $122 \mathrm{~m} \mathrm{~A}$ & - \\
\hline 149 & 26.11 .09 & plume site seg. $3 \mathrm{~B}, \mathrm{~T}-\mathrm{Y}$ & $09^{\circ} 45.86^{\prime} \mathrm{S}, 155^{\circ} 02.46^{\prime} \mathrm{E}$ & $3580 \mathrm{~m}$ & $201 \mathrm{~m} \mathrm{C}$ & - \\
\hline \multirow[t]{2}{*}{150} & 26.11 .09 & plume site seg. 3B, TVG & $09^{\circ} 47.90^{\prime} \mathrm{S}, 155^{\circ} 03.17^{\prime} \mathrm{E}$ & $3374 \mathrm{~m}$ & $25 \mathrm{~m}$ & - \\
\hline & & & & & & \\
\hline 142 & 24.11 .09 & Flat-top volcano, 4A, DR & $09^{\circ} 34.41^{\prime} \mathrm{S}, 155^{\circ} 16.10^{\prime} \mathrm{E}$ & $3887 \mathrm{~m}$ & $153 \mathrm{~m}$ & FG \\
\hline 143 & 24.11 .09 & E part of segment $4 \mathrm{~A}, \mathrm{DR}$ & $09^{\circ} 31.55^{\prime} \mathrm{S}, 155^{\circ} 23.39^{\prime} \mathrm{E}$ & $3920 \mathrm{~m}$ & $272 \mathrm{~m} \mathrm{~A}$ & - \\
\hline 144 & 25.11 .09 & E part of segment $4 \mathrm{~A}, \mathrm{DR}$ & $09^{\circ} 30.65^{\prime} \mathrm{S}, 155^{\circ} 24.85^{\prime} \mathrm{E}$ & $4000 \mathrm{~m}$ & $242 \mathrm{~m}$ & FG \\
\hline 146 & 25.11 .09 & segment $4 \mathrm{C}, \mathrm{DR}$ & $09^{\circ} 33.89^{\prime} \mathrm{S}, 155^{\circ} 41.59^{\prime} \mathrm{E}$ & $3655 \mathrm{~m}$ & $148 \mathrm{~m}$ & FG \\
\hline 147 & 25.11 .09 & segment $4 \mathrm{C}, \mathrm{DR}$ & $09^{\circ} 33.30^{\prime} \mathrm{S}, 155^{\circ} 43.61^{\prime} \mathrm{E}$ & $3554 \mathrm{~m}$ & $218 \mathrm{~m} \mathrm{~A}$ & FG \\
\hline
\end{tabular}

${ }^{a}$ Water depth gives the deepest part of the sampling track; MARP depth gives the maximum distance between the instrument and seafloor; it is calculated as maximum depth minus deepest recording from MAPR, thus this distance is much exaggerated for operations during which the water depth changed a lot $(\mathrm{A}=$ more than $50 \mathrm{~m}$ depth change during operation, $\mathrm{B}=$ more than $100 \mathrm{~m}$ depth change during operation, $\mathrm{C}=$ about $300 \mathrm{~m}$ depth change during operation). Other abbreviations: $\mathrm{CTD}=$ conductivity-temperature-density package, $\mathrm{VSR}=$ volcanic rock corer, $\mathrm{DR}=\mathrm{dredge}$, $\mathrm{T}-\mathrm{Y}=$ tow-yo profile, $\mathrm{TVG}=\mathrm{TV}-\mathrm{Grab} ; \mathrm{FG}=$ Fresh glass, $\mathrm{AG}=$ Altered glass, $-=$ no recovery.

covered by MAPR deployment was $14.5 \mathrm{~km}$ ), so the chance of detecting a plume was higher. Also, the axial valleys here are hundreds of meters deep, with sampling concentrated around the central, shallowest portions of each segment. Experience from plume sampling along the deep Gakkel Ridge [Edmonds et al., 2003] suggests that the probability of plume detection was likely higher in these segments than along Segments 1 and 2. First, plumes are trapped in the deep valleys between the transform faults, and can spread farther along axis. Second, plume rise increases at deeper depths owing to reduced vertical density gradients in the bottom waters, so plume detection would have been likely 


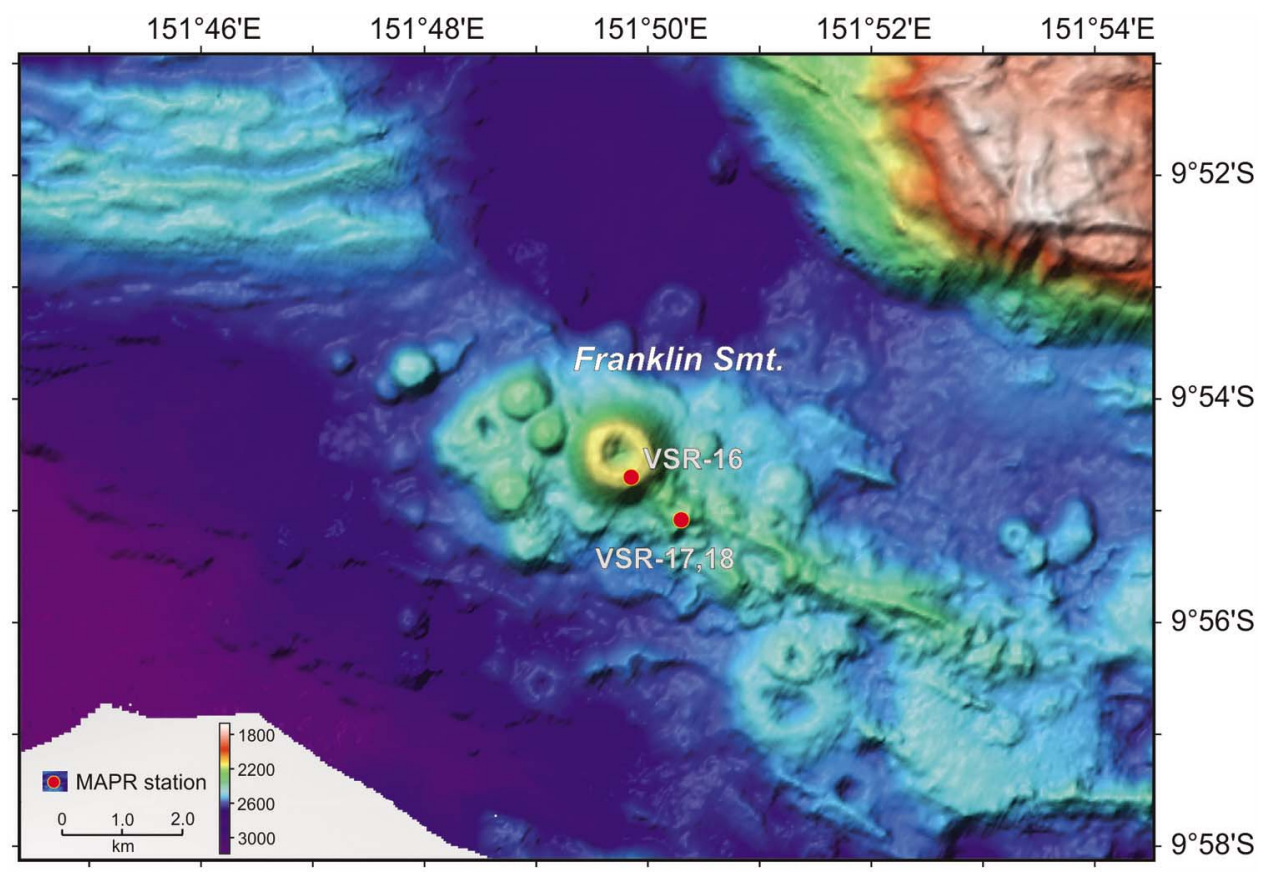

Figure 3. Detailed bathymetric map of Franklin Seamount (for regional setting see Figures 1 and 2), a flat-topped volcano with a central crater typical of oceanic spreading centers [e.g., Smith and Cann, 1990]. It is the only known location of present-day hydrothermal activity in the western Woodlark Basin. The sampling sites near Franklin Seamount are marked in the figure (VSR = volcanic corer).

even during MAPR deployments that did not come within $200 \mathrm{~m}$ of the seafloor (Table 1). Although we expect that plumes from high-temperature venting were readily detected even under this altitude constraint, some low-temperature, diffuse hydrothermal venting may have been missed.

\section{Results}

[12] Of the 38 MAPR deployments in or near the neovolcanic zone, only sites near Franklin Seamount and near the eastern tip of Segment 3 yielded evidence of active hydrothermal venting based on significant and repeatable NTU and/or $\mathrm{dE} / \mathrm{dt}$ anomalies.

\subsection{Franklin Seamount}

[13] Franklin Seamount (Figure 3) is one of numerous flat-topped volcanic edifices found in the Woodlark Basin. It had previously been found to be hydrothermally active [Lisitzin et al., 1991]. During the SO-203 cruise, we mapped the edifice and its surroundings in detail using an autonomous underwater vehicle (AUV) [Devey et al., 2010] and carried out a TV-grab station within the crater (TVG-24) that included a $\sim 1 \mathrm{~km}$ long video track.
[14] The observations made in 2009 were significantly different from the descriptions made 20 years ago [Lisitzin et al., 1991; Binns et al., 1993, 1997; Bogdanov et al., 1997]. We found neither the spires of barite nor the areas of shimmering water described by Lisitzin et al. [1991]. Sampling at the crater floor in the SW corner of the volcano recovered orange-brown porous material ( $\mathrm{Fe}-\mathrm{Si}-\mathrm{Mn}$ oxyhydroxides), similar to material described in previous studies. The extent of hydrothermal activity visible within the volcano crater appears to have significantly decreased during the last 20 years. The water column directly above the whole Franklin summit area was also surveyed by the AUV diving at $\sim 2100 \mathrm{~m}$, slightly above the summit plateau (plateau depth $\sim 2150 \mathrm{~m}$ ), and at $2130 \mathrm{~m}$ above the crater (depth of crater floor ca. $2250 \mathrm{~m}$ ). The vehicle detected no NTU or dE/dt anomalies, reinforcing the conclusion that the crater of Franklin Seamount is no longer hydrothermally active. We did, however, find weak $\triangle \mathrm{NTU}$ and $\mathrm{dE} / \mathrm{dt}$ anomalies at stations VSR-17 and 18 slightly SE from Franklin Seamount, on a linear volcanic ridge interpreted to be produced by a small fissure eruption (station location see Figure 3). At VSR-17, a plume signature with small dE/dt $(\sim-0.02 \mathrm{mV} / \mathrm{s})$ and $\Delta \mathrm{NTU}(\sim 0.007)$ anomalies was found 70-200 $\mathrm{m}$ above the top of 


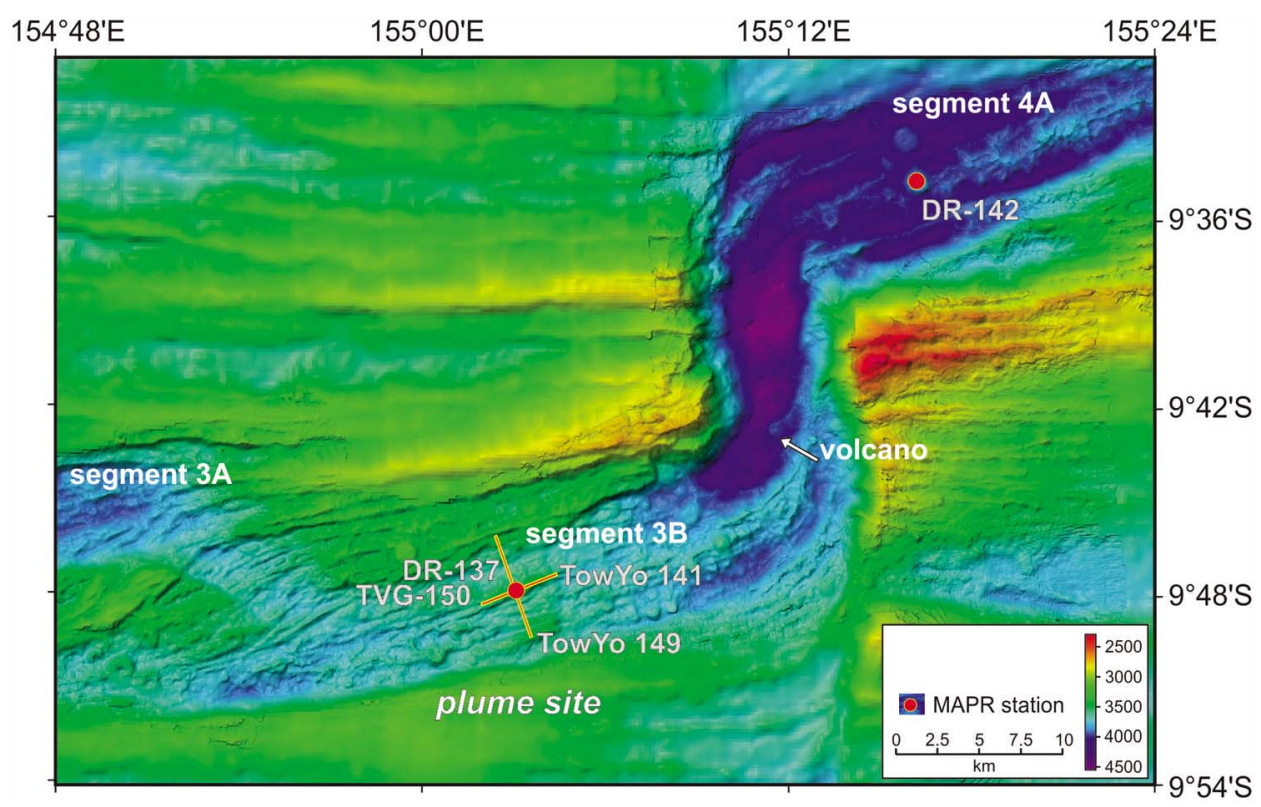

Figure 4. Detailed bathymetric map of the seafloor near the transform fault between segments 3 and 4 . Survey sites $(\mathrm{DR}=$ dredge, $\mathrm{TVG}=\mathrm{TV}$-grab, TowYo $=$ towed hydrothermal profiler $)$ near the only significant neutrally buoyant plume found during SO-203 are shown. An example of a volcanic edifice within the transform fault is marked.

the ridge, peaking at around $2180 \mathrm{~m}$ water depth, close to the depth of the summit plateau of Franklin. This anomaly was not detected during a second sampling at this depth (Figure 3), although VSR-18 did record a very small but repeatable $\mathrm{dE} / \mathrm{dt}$ anomaly near $2040 \mathrm{~m}$. Fresh glass was recovered at station VSR-16, whereas other stations (VSR-13, $-18)$ near this topographic high yielded samples showing signs of alteration or sediment cover.

\subsection{Segment 3B Site}

[15] An extensive plume was discovered on Segment 3B during dredging at station DR-137 (Figure 4). The results from station DR-137 showed a prominent anomaly in all measured properties $(\mathrm{dE} / \mathrm{dt}<-0.04 \mathrm{mV} / \mathrm{s}, \Delta \mathrm{NTU} \sim 0.3$, and a temperature anomaly $>0.01^{\circ} \mathrm{C}$ ) at the depth of $\sim 2820$ $2920 \mathrm{~m}$, some $300-500 \mathrm{~m}$ above the seafloor. Based on this information the anomaly was further mapped with 2 tow-yo profiles (TowYo-141 and TowYo-149; Figures 5 and 6).

[16] The dE/dt and $\Delta$ NTU transects from stations TowYo-141 and TowYo-149 are shown in Figure 5. These plots show the presence of two distinct anomalies (one centered on $\sim-2900 \mathrm{~m}$, the other, less intense, anomaly centered on $-3200 \mathrm{~m}$ ) and variations in the height of the center of the shallower anomaly of up to $200 \mathrm{~m}$. These height variations are robust evidence of both low- and high-temperature discharge nearby. The ORP and $\triangle \mathrm{NTU}$ anomalies overlap, with the ORP anomaly showing a particularly strong change in depth around $155.052^{\circ} \mathrm{E}$ (TowYo-141) and $9.802^{\circ} \mathrm{S}$ (TowYo-149). The presence of an ORP anomaly, indicating reduced species in the water column and hence suggestive of proximity to a source of buoyant fluid, encouraged a TVgrab station (TVG-150) close to the intersection of the tow-yo lines (see Figure 6). Sparse fauna, typical of near-vent assemblages (including galatheid crabs of the Munidopsis genus) were observed, but no active venting was found during this deployment.

[17] No other signs of present-day hydrothermal activity were found on any of the other segments.

\section{Discussion}

\subsection{Frequency of Active Hydrothermal Sites}

[18] The four segments of the Woodlark Basin axis studied here can be classified as either slow or intermediate spreading centers $(36-67 \mathrm{~mm} / \mathrm{yr}$ full spreading rate). Baker and German [2004] showed that the magmatic budget of the ridge is the main controlling factor on abundance of hydrothermal activity detected at the spreading axis. They showed that typical slow-spreading centers $(20-55 \mathrm{~mm} / \mathrm{yr}$ full spreading rate) have a plume incidence $\left(\mathrm{F}_{\mathrm{s}}\right.$; defined as the number of active vent fields per 


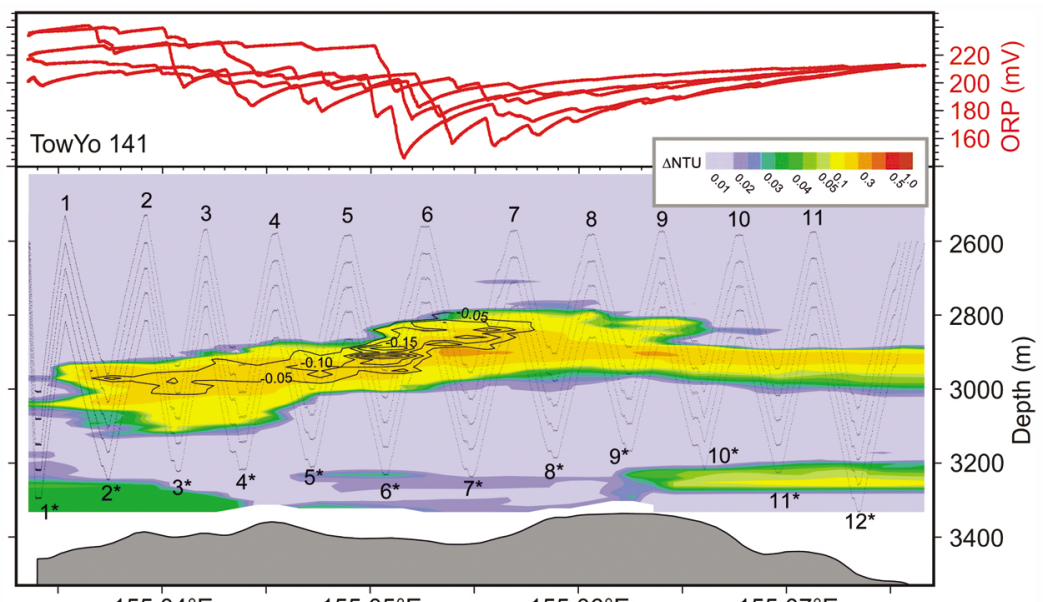

$\begin{array}{llll}155.04^{\circ} \mathrm{E} & 155.05^{\circ} \mathrm{E} & 155.06^{\circ} \mathrm{E} & 155.07^{\circ} \mathrm{E}\end{array}$

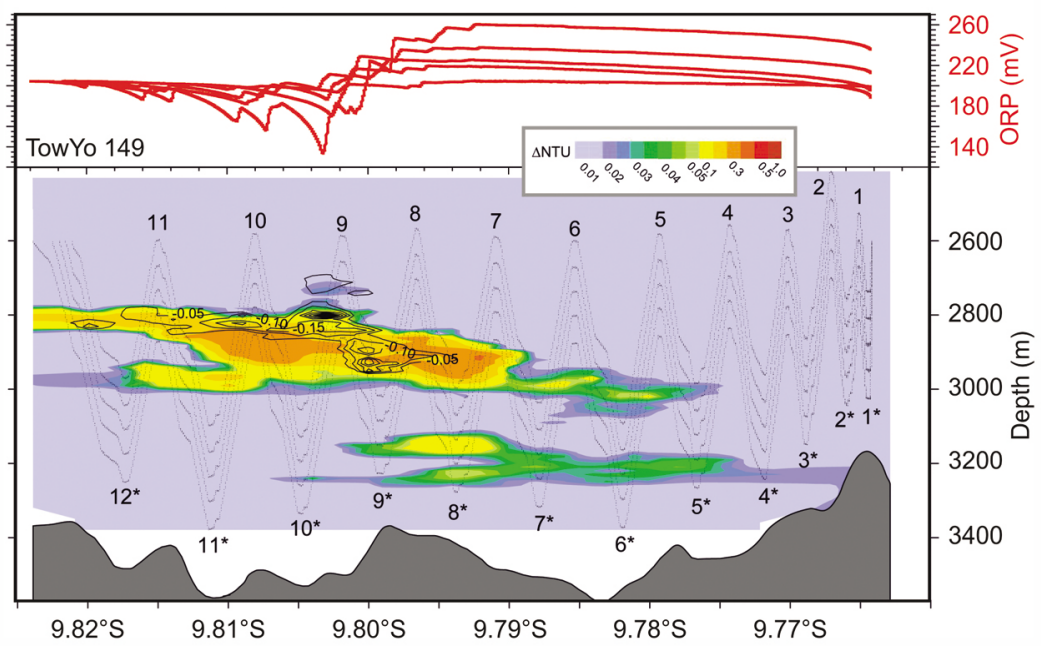

Figure 5. Information from the tow-yo profiles near the plume site on Segment 3 (for details of profile locations see Figures 4 and 6). Also marked with numbers are the tow-yo upper and lower turning points corresponding to the white (lower, asterisk) or red (upper) numbers marked on Figure 6. The intensity of the turbidity anomaly $(\Delta N T U)$ is contoured in the profiles using results from the 5 MAPR (the track of each MAPR reconstructed from its pressure readings and the position of a USBL-transponder on the depressor weight is shown as a thin gray trace). The red lines at the top of each figure component show oxidation-reduction potential (ORP in $\mathrm{mV}$ ) in each of the MAPRs. Note that, although the absolute ORP values drift with time, the rate of change $(\mathrm{dmV} / \mathrm{dt})$ is proportional to the strength of the ORP anomaly. The bathymetry is shown on the bottom of the profiles. We observe a large shallow anomaly at depth $\sim 2900 \mathrm{~m}$ and a smaller deep anomaly at $\sim 3200 \mathrm{~m}$.

$100 \mathrm{~km}$ of ridge length) of 1.5 (ranging from $\sim 0.5$ to 3.0); for intermediate and fast spreading ridges ( $>55 \mathrm{~mm} / \mathrm{yr}$ full spreading rate) the values are higher (for example, at $60 \mathrm{~mm} / \mathrm{yr}$ and average thickness of crust, $F_{\mathrm{s}}=\sim 1.9$ ). Work on the slowly spreading Mid-Atlantic Ridge based on new site discoveries by Cherkashov et al. [2010] found an $\mathrm{F}_{\mathrm{s}}$ there of $\sim 1$; a similar evaluation was given by German [2009].

[19] Although in view of its spreading rates (36 to $53 \mathrm{~mm} / \mathrm{yr}$ ) the western part of the Woodlark Basin is classified as slow-spreading, its axis shows more "fast-spreading" characteristics than the eastern basin [Martinez et al., 1999]. Most importantly, Segments 1 and 2 apparently have an anomalously high magmatic budget. The high magmatic budget ( $9 \mathrm{~km}$ thick crust, average spreading rate of $45 \mathrm{~mm} / \mathrm{yr}$, after Martínez et al. [1999]) leads to a calculated expected $\mathrm{F}_{\mathrm{s}}$ of 1.9 using the formulae of Baker and German [2004]. Thus finding only one very weak hydrothermal signal (Franklin) along Segments 1 and $2\left(\sim 280 \mathrm{~km}\right.$ of ridge, $\left.F_{\mathrm{s}}=0.36\right)$ is very anomalous.

[20] Even if we combine all known hydrothermal sites in Woodlark (Franklin, Segment 3B and the site on Segment 5B discovered by Leybourne et al. (manuscript in preparation, 2012)) we have only 


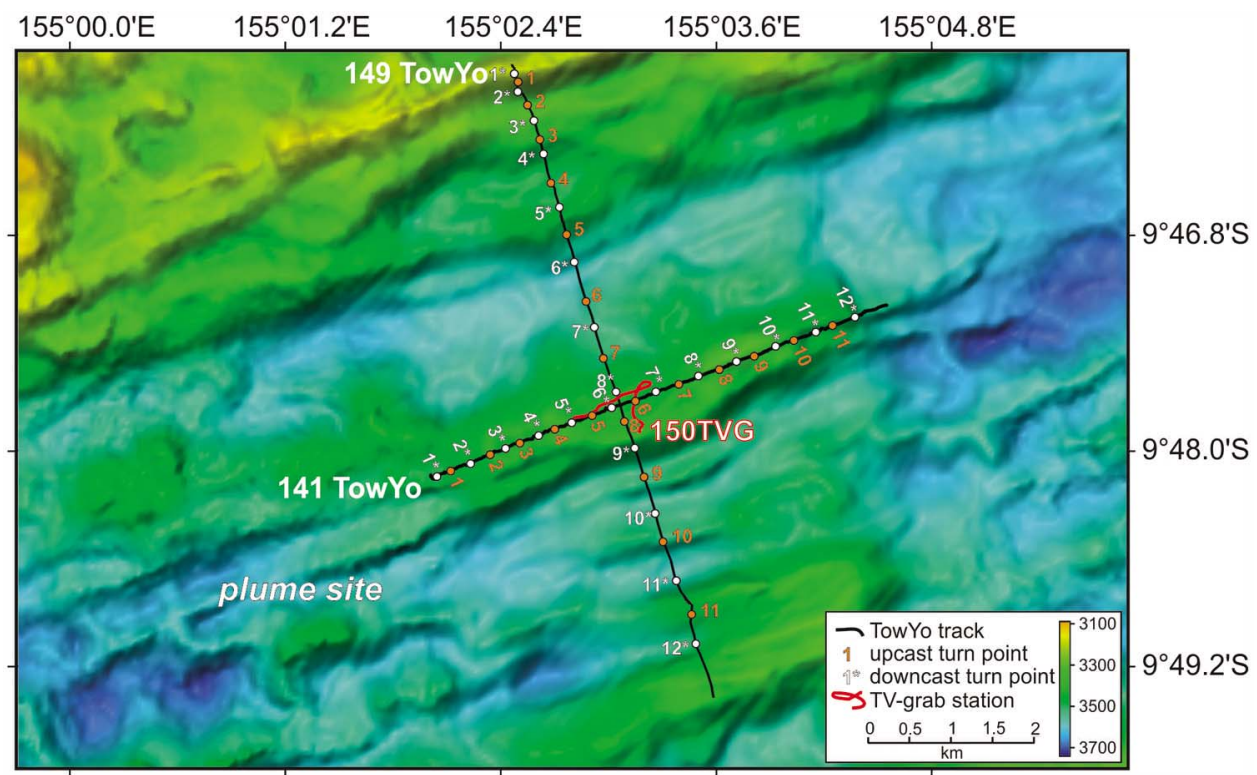

Figure 6. The detailed location of the Tow-Yo profiles near the plume site. The white numbers with asterisks refer to lower turning points and the red numbers to upper turning points. The track of the TV-Grab study conducted near the intersection of the profiles is shown with a red line. The survey did not find the location of hydrothermal venting, but indications of hydrothermal activity, in the form of near-vent fauna, were observed.

three sites over $520 \mathrm{~km}$ of ridge axis, giving an $\mathrm{F}_{\mathrm{s}}=$ 0.58 , at the low end of previous work on slow- and especially intermediate-spreading ridges. Another way of characterizing the spatial density of venting when using discrete rather than continuous (as in a ridge-length tow-yo) sampling is to calculate plume incidence, the fraction of profiles on which plumes were detected. Scheirer et al. [1998] showed that discrete sampling of ridges at intervals of 10, 20 and $40 \mathrm{~km}$ sampling resulted in plume detection within $5-10 \%$ of the results from continuous sampling. Plume detection on 3 of 38 profiles yields a plume incidence of 0.08 , more consistent with ultra-slow than slow-spreading ridges [Baker and German, 2004], especially considering the very weak plume signals on the two profiles near Franklin Seamount. Thus, we interpret the Woodlark spreading centers to be less hydrothermally active than typical MOR spreading centers with spreading rates of $30-70 \mathrm{~mm} / \mathrm{yr}$, with particularly the western part of the basin showing extremely low plume activity. In the following, we present a number of possible explanations.

\subsection{Tectonic Peculiarities}

[21] In the Woodlark Basin, spreading has been characterized by both repeated ridge jumps and changes in axis orientation and one Euler Pole relocation. The results of the ridge jumps are seen as multiple abandoned spreading ridges with slightly different strikes (Figures 1 and 2) [also Taylor et al., 1999]. Due to proximity to the Euler Pole, northsouth relocation of the axis also involves a relatively large change in strike; nevertheless, jump-related changes in strike are small compared to the major effect on strike of all the axes in connection to the Euler Pole relocation. Although it is not uncommon for spreading ridges elsewhere to relocate, large synchronous axial jumps appear to be much rarer. Thus in the Lau Basin, Taylor et al. [1996] show that changes in ridge position and transfer of lithosphere from one plate to another occur by ridge propagation, not jumping. Opening of the Protector Basin (Scotia Arc) by progressive propagation has been shown by Galindo-Zaldivar et al. [2006], while at the Macquarie Ridge a $60^{\circ}$ change in spreading direction has been shown to be accommodated by shrinkage of segments without their relocation [Mosher and Symons, 2008]. Thus the large ridge jumps experienced by the Woodlark segments, especially shortly after their initiation, appear to be a peculiar tectonic feature of the Basin.

[22] The Euler Pole relocation at Woodlark at $\sim 0.52 \mathrm{Ma}$ and a synchronous reorientation of the $500-\mathrm{km}$-long spreading axis around $80 \mathrm{ka}$ [Goodliffe et al., 1997] is reflected in a mis-alignment of the present-day axis with the boundary of the region of seafloor formed during the Bruhnes magnetic 
period (Figures 1 and 2) [also Goodliffe et al., 1997]. The present-day axes of Segments $1 \mathrm{~b}$ and 2 are not centrally located in the zone of normally magnetized seafloor, implying that not all that seafloor has been produced from an axis occupying the present-day position and that seafloor has been transferred from one plate to the other. The more easterly segments $(3 b, 4$ and 5) are presently more symmetrically positioned within the Bruhnes crust, although the trends of the individual axial segments are oblique to the trend of the axial valley or the Bruhnes boundary. Evidence from magnetic studies (e.g., the doubling of magnetic anomaly 2 to the north of Segment 3 [Taylor et al., 1999]) suggests that Segments 3 and 4 previously also experienced ridge jumps shortly after their creation.

[23] The pole relocation also caused the pre-existing narrow strike-slip faults (e.g., Moresby transform fault, between Segments 2 and 3 and transform connecting Segments 3 and 4, see Figure 2) to open in a pull-apart fashion and to develop their own neovolcanic zones with volcanic edifices (an example, which also shows high sonar backscatter, is shown in Figure 4). The effects of the reorientation are also reflected in the width of the neovolcanic regions, which is exceptionally large along parts of the Woodlark Basin. (The neovolcanic zone on Segments 1 and 2 is the area showing strong acoustic backscatter; on Segments 3 and 4 it is the area within the fault-bounded axial valley. Goodliffe et al. [1997] defined this latter region as containing unrifted crust.) For example, on Segment 1 the acoustically defined neovolcanic zone is $\sim 10 \mathrm{~km}$ (independently confirmed by sampling of fresh rocks from the center of Segment $1 \mathrm{~A}$ to $7 \mathrm{~km}$ off axis (VSR-50, 51, 52, 53, 54 and 107; Table 1 and Figure 2)) and on Segment 4 $8 \mathrm{~km}$ across; this is significantly wider than concluded for intermediate-spreading ridges $(<2 \mathrm{~km}$ [Macdonald, 1982]) or even for slowly spreading ridges $(\sim 5 \mathrm{~km}$ at the Mid-Atlantic Ridge (MAR) $45^{\circ} \mathrm{N}$ [Searle et al., 2010]), suggesting that magmatic activity is more widely distributed in the Woodlark Basin than at other slow- and intermediate spreading centers.

\subsection{Magmatic Activity}

[24] One possible explanation for a lower incidence of hydrothermal activity in the Woodlark Basin when compared to ridges of similar spreading rates would be a lower magmatic heat input to the axis. We know, however, from our successful sampling of fresh lavas that the spreading axes are volcanically active, although we have no information about the frequency of magmatic activity at a particular place on the Woodlark axis. We see no bathymetric or sampling evidence that tectonic spreading or core complex formation as, for example, along the MidAtlantic ridge [e.g., Escartín et al., 2008] is occurring in the Woodlark Basin, suggesting that crustal formation is occurring primarily by magmatic accretion. Martínez et al. [1999] have previously shown that at least Segments 1 and 2 are characterized by thicker-than-average crust and that this crust is probably magmatic. We do not, therefore, see any reason to conclude that the overall amount of magmatic heat being input to the crust is less at Woodlark than at more mature mid-ocean ridges with similar spreading rates and that it may, in the western half of the basin at least, even be higher.

[25] Franklin Seamount, site of the only hydrothermal signal in the western Basin, is one of numerous flat-topped volcanic edifices present in the neovolcanic zone throughout the Basin. This vent site is likely eruption-related and unlikely to produce long-lived hydrothermal discharge, crucial for formation of significant seafloor massive sulfide (SMS) deposits, due to the small size of the volcano [Fouquet et al., 2010; Hannington et al., 2011]. In the early 1990s Franklin Seamount was shown to have significant mineralization potential and evidence of high-temperature venting within the summit crater [Lisitzin et al., 1991], although it was also shown that the hydrothermal deposits were relatively thin and young. Binns et al. [1993] presented radiometric and sedimentological evidence showing that the hydrothermal activity began some 200 yrs. ago. Hyaloclastite fragments in the earliest-formed hydrothermal deposits suggest that their formation was initiated immediately post-eruption. No evidence for subsequent eruptions was found. Our observations of an extinct or almost extinct circulation system with no hydrothermal plume rising above the summit plateau suggests a decrease in hydrothermal activity during the last 20 years and, combined with the radiometric evidence that activity is only ca. 200 yrs. old, that the magmatic heat source driving the circulation was small. Franklin Seamount is the largest of a group of circular cratered and non-cratered seamounts in this region (see Figure 3). If the other seamounts in this area also represent the products of individual eruptive events and if their hydrothermal systems were similar to that seen at Franklin, then the amount of heat provided by these individual magma pulses is likely to be too small to support the formation of stable, long-lived hydrothermal systems, a precondition for significant seafloor mineralization. Short-lived, 
magma-driven hydrothermal activity has been confirmed on other ridges. On the Gorda Ridge in the northeast Pacific, an intermediate-spreading ridge with slow-spreading morphology, a documented eruption created new high-temperature hydrothermal fields and two event plumes in February 1996 [Baker, 1998]. By August 1996, however, hightemperature venting could not be found, and apparently only sporadic, low-temperature discharge remained [Massoth et al., 1998].

\subsection{Role of Faults}

[26] Most of the faults on mid-ocean ridges occur near the rift axis, thus the repeated relocations of the Woodlark axis might be expected to cause the faults to be frequently relocated. Changes in the directions of the principle stresses acting on the plates, coincident with the recent change in the location of the Euler Pole, would have led to deactivation of preexisting faults and opening of new ones, changing the pathways for both magmas and possible hydrothermal fluids. The instability of the fault network has implications for modern hydrothermal activity and the mineralization potential of the Woodlark axis as both are directly linked to long-lived, faultrelated hydrothermal discharge [e.g., Fouquet et al., 2010; Cherkashov et al., 2010].

[27] In this respect it is noteworthy that the only two substantial neutrally buoyant hydrothermal plumes so far detected in the Woodlark Basin are located on the older and faster-spreading eastern segments. Although this follows the general global pattern of increasing hydrothermal activity with increasing spreading rate [Baker and German, 2004], our observation of no significant hydrothermal activity over Segments 1 and 2 supports the interpretation that spatially large ridge jumps (not confined to jumps or re-orientations within the neovolcanic zone as commonly observed from other ridges, but creating a completely new axial region, see discussion above) inhibit creation of stable hydrothermal plumbing system.

[28] At slow-spreading ridges, most mineral deposits are situated on large faults that run either parallel or perpendicular to the ridge axis. Cherkashov et al. [2010], for example, found 4 of 6 deposits on the MAR flanks to be located near large faults; the age range covered by the deposits correlated positively with their size. The well-studied TAG site at $26^{\circ} \mathrm{N}$ on the Mid-Atlantic Ridge is located on a large fault marking the eastern margin of the axial valley and the mineralization is suggested to be caused by fluid flow along normal faults connecting it to the slowly spreading axis, [e.g., deMartin et al., 2007]. At TAG, the hydrothermal activity began about 100 to $150 \mathrm{ka}$ ago and the sulfide deposition developed to its full extent 50-100 ka ago [Lalou et al., 1995]. This is consistent with a stable heat source and deepseated, long-lived $(\sim 100 \mathrm{ka})$ faults being crucial for the formation of large sulfide mineral deposits such as TAG ( 4 Mt) [Hannington et al., 1998] or Semyenov (>13 Mt) [Cherkashov et al., 2010].

\subsection{The Paucity of Plumes at Woodlark}

[29] Based on our observations we suggest that a combination of several factors makes the Woodlark Basin less hydrothermally active than might be expected from spreading rate and apparent magma supply. First, due to the unstable tectonic situation the ridge axis changes location relatively often, either by ridge jumps or through re-orientation, prohibiting formation of a stable heat source over prolonged times. Second, the neovolcanic zone is exceptionally wide, implying that the available heat is probably released unfocused, mitigating against the establishment of a long-term stable heat source necessary for intense, long-lived hydrothermal circulation. Finally, changes in intraplate stress associated with the variability of the tectonic reconfigurations may result in frequent changes of the position of hydrothermal discharge through time. Combined, these factors distribute the heat through the crust-water interface over a region that is much larger than at other axes with similar spreading rates and this scenario is not conducive to forming longlived high-temperature fields. If this conclusion is correct, it is unlikely that hydrothermal systems could be sustained, particularly on the western Woodlark spreading axis, long enough to produce large SMS deposits.

\section{Conclusions}

[30] We sampled and prospected for hydrothermal activity along $435 \mathrm{~km}$ of the $520-\mathrm{km}$-long slowto intermediate-spreading axis in the Woodlark Basin. Most of the stations returned fresh, glassy basalt. However, we found only one prominent hydrothermal plume, in the faster-spreading eastern part of the investigated area. An additional small hydrothermal anomaly was found near Franklin Seamount, although activity at the seamount itself (which was shown to be hydrothermally active 20 years ago) seems to have ceased. Besides these 2 hydrothermal occurrences, only one other plume site, which had previously been discovered east of our study area, is known from the Woodlark spreading axis. Together, 
these three sites imply a site density (active sites/ $100 \mathrm{~km}$ of ridge; $\mathrm{F}_{\mathrm{s}}$ ) of $\sim 0.58$ for the entire Woodlark Basin axis, or a plume incidence in our $435 \mathrm{~km}$ survey area of 0.08 . Both are at the low end of values observed at ridges of similar spreading rates. If we take into account that the western and eastern halves of the basin have different crustal structure, the plume deficit in the western Woodlark Basin ( $280 \mathrm{~km}$ of ridge axis) becomes even more striking, with $\mathrm{F}_{\mathrm{s}}$ of 0.36 (compared to a predicted $F_{\mathrm{s}}$ of 1.9). We suggest that this anomalously low site density results from frequent jumps in axis location as spreading progresses westward, compounded by a change in rifting direction $\sim 80,000$ yrs. ago. As a result, the initial phases of seafloor magmatism at Woodlark produce a neovolcanic zone up to twice as wide as that at other slow- or intermediate-spreading ridges and lacking a stable heat source necessary to drive long-lived hydrothermal circulation. We conclude that, compared to other similar spreading centers, much of the Woodlark crust is cooled to a larger degree by either diffuse venting over large areas or by short-lived hydrothermal systems tied to individual extrusive or intrusive magmatic events. Changes in spreading direction, and hence intraplate stress field, which lead to frequent abandonment or re-activation of crustal fractures will also prevent high-temperature venting in one stable location over the extended periods (>100 ka) necessary to form significant metal deposits. In combination, these factors lead us to suggest that large SMS deposits, such as those found on the Mid-Atlantic Ridge, may not exist in the western Woodlark Basin.

\section{Acknowledgments}

[31] We wish to thank the Captain and Crew of F.S. "Sonne" for their excellent support during the SO-203 cruise. Fernando Martinez (Hawaii) provided bathymetric, side scan and magnetic data, which helped enormously in cruise planning. He and Andrew Goodliffe are thanked for insightful reviews that greatly improved the manuscript. The assistant editor Robert Dunn is thanked for editorial handling. The SO-203 cruise was supported by BMBF grant 03G0203A to CWD and an NSERC Discovery Grant to MDH. PMEL contribution 3877.

\section{References}

American Public Health Association (1985), Standard Methods for the Examination of Water and Wastewater, 16th ed., 1268 pp., Washington, D. C.

Baker, E. T. (1998), Patterns of event and chronic hydrothermal venting following a magmatic intrusion: New perspectives from the 1996 Gorda Ridge eruption, Deep Sea Res., Part II, 45, 2599-2618, doi:10.1016/S0967-0645(98) 00085-X.
Baker, E. T., and C. R. German (2004), On the global distribution of hydrothermal vent fields, in Mid-Ocean Ridges: Hydrothermal Interactions Between the Lithosphere and Oceans, Geophys. Monogr. Ser., vol. 148, edited by C. R. German, J. Lin, and L. M. Parson, pp. 245-266, AGU, Washington, D. C., doi:10.1029/148GM10.

Baker, E. T., C. R. German, and H. Elderfield (1995), Hydrothermal plumes over spreading-center axes: Global distributions and geological inferences, in Seafloor Hydrothermal Systems: Physical, Chemical, Biological, and Geological Interactions, Geophys. Monogr. Ser., vol. 91, edited by S. Humphris et al., pp. 47-71, AGU, Washington, D. C., doi:10.1029/GM091p0047

Baker, E. T., F. Martinez, J. A. Resing, S. L. Walker, N. J. Buck, and M. H. Edwards (2010), Hydrothermal cooling along the Eastern Lau Spreading Center: No evidence for discharge beyond the neovolcanic zone, Geochem. Geophys. Geosyst., 11, Q08004, doi:10.1029/2010GC003106.

Binns, R. A., et al. (1993), Hydrothermal oxide and gold-rich sulfate deposits on Franklin Seamount, Western Woodlark Basin, Papua New Guinea, Econ. Geol., 88(8), 2122-2153, doi:10.2113/gsecongeo.88.8.2122.

Binns, R. A., J. M. Parr, J. B. Gemmell, D. J. Whitford, and J. A. Dean (1997), Precious metals in barite-silica chimneys from Franklin Seamount, Woodlark Basin, Papua New Guinea, Mar. Geol., 142(1-4), 119-141, doi:10.1016/S0025-3227(97) 00047-9.

Bogdanov, Y. A., A. P. Lisitzin, R. A. Binns, A. I. Gorshkov, E. G. Gurvich, V. A. Dritz, G. A. Dubinina, O. Y. Bogdanova, A. V. Sivkov, and V. M. Kuptsov (1997), Low-temperature hydrothermal deposits of Franklin Seamount, Woodlark Basin, Papua New Guinea, Mar. Geol., 142(1-4), 99-117, doi:10.1016/S0025-3227(97)00043-1.

Cherkashov, G., et al. (2010), Seafloor massive sulfides from the northern equatorial Mid-Atlantic Ridge: New discoveries and perspectives, Mar. Georesour. Geotechnol., 28(3), 222-239, doi:10.1080/1064119X.2010.483308.

deMartin, B., R. Sohn, J. Pablo Canales, and S. Humphris (2007), Kinematics and geometry of active detachment faulting beneath the Trans-Atlantic Geotraverse (TAG) hydrothermal field on the Mid-Atlantic ridge, Geology, 35(8), 711-714, doi:10.1130/G23718A.1.

Devey, C. W., S. Petersen, M. D. Hannington, I. Klaucke, K. S. Lackschewitz, J. Mahlke, M. Rothenbeck, and J. Sticklus (2010), Constructing mid-ocean ridge flat-topped volcanoes: First evidence from AUV mapping in the Woodlark Basin, Abstract V12A-06 presented at 2010 Fall Meeting, AGU, San Francisco, Calif., 13-17 Dec.

Edmonds, H. N., P. J. Michael, E. T. Baker, D. P. Connelly, J. E. Snow, C. H. Langmuir, H. J. B. Dick, R. Mühe, C. R. German, and D. W. Graham (2003), Discovery of abundant hydrothermal venting on the ultraslow-spreading Gakkel Ridge, Arctic Ocean, Nature, 421, 252-256, doi:10.1038/ nature 01351.

Escartín, J., D. K. Smith, J. Cann, H. Schouten, C. H. Langmuir, and S. Escrig (2008), Central role of detachment faults in accretion of slow-spreading oceanic lithosphere, Nature, 455(7214), 790-794, doi:10.1038/nature07333.

Ferris, A., G. A. Abers, B. Zelt, B. Taylor, and S. Roecker (2006), Crustal structure across the transition from rifting to spreading: The Woodlark rift system of Papua New Guinea, Geophys. J. Int., 166(2), 622-634, doi:10.1111/j.1365-246X. 2006.02970.x.

Fouquet, Y., et al. (2010), Geodiversity of hydrothermal processes along the Mid-Atlantic Ridge and ultramafic-hosted 
mineralization: A new type of oceanic $\mathrm{Cu}-\mathrm{Zn}-\mathrm{Co}-\mathrm{Au}$ volcanogenic massive sulfide deposit, in Diversity of Hydrothermal Systems on Slow Spreading Ocean Ridges, Geophys. Monogr. Ser., vol. 188, edited by P. A. Rona et al., pp. 321-367, AGU, Washington, D. C., doi:10.1029/2008GM000746.

Galindo-Zaldívar, J., F. Bohoyo, A. Maldonado, A. Schreider, E. Suriñach, and J. T. Vázquez (2006), Propagating rift during the opening of a small oceanic basin: The Protector Basin (Scotia Arc, Antarctica), Earth Planet. Sci. Lett., 241, 398-412, doi:10.1016/j.epsl.2005.11.056.

German, C. (2009), Global distributions and geodiversity of high-temperature seafloor venting, paper presented at Science and Policy Workshop: Deep-Sea Mining of Seafloor Massive Sulfides: A Reality for Science and Society in the 21st Century, Woods Hole Oceanogr. Inst., Woods Hole, Mass.

Goodliffe, A. M., B. Taylor, F. Martinez, R. Hey, K. Maeda, and K. Ohno (1997), Synchronous reorientation of the woodlark basin spreading center, Earth Planet. Sci. Lett., 146(1-2), 233-242, doi:10.1016/S0012-821X(96)00227-0.

Hannington, M., A. Galley, P. Herzig, and S. Petersen (1998), Comparison of the TAG mound and stockwork complex with Cyprus-type massive sulfide deposits, Proc. Ocean Drill. Program Sci. Results, 158, 389-415.

Hannington, M. D., J. Jamieson, T. Monecke, S. Petersen, and S. Beaulieu (2011), The abundance of seafloor massive sulfide deposits, Geology, 39(12), 1155-1158, doi:10.1130/ G32468.1.

Kington, J. D., and A. M. Goodliffe (2008), Plate motions and continental extension at the rifting to spreading transition in Woodlark Basin, Papua New Guinea: Can oceanic plate kinematics be extended into continental rifts?, Tectonophysics, 458 , 82-95, doi:10.1016/j.tecto.2007.11.027.

Lalou, C., J.-L. Reyss, E. Brichet, P. A. Rona, and G. Thompson (1995), Hydrothermal activity on a $10^{5}$-year scale at a slowspreading ridge, TAG hydrothermal field, Mid-Atlantic Ridge $26^{\circ}$ N, J. Geophys. Res., 100, 17,855-17,862, doi:10.1029/ 95JB01858.

Lisitzin, A. P., R. A. Binns, Y. A. Bogdanov, S. D. Scott, L. P. Zonenshain, V. V. Gordeev, E. G. Gurvich, K. G. Muraviov, and V. V. Serova (1991), Present-day hydrothermal activity of Franklin Seamount, western Woodlark Basin, Papua New Guinea [in Russian], Izv. Acad. Sci. USSR, Geol. Ser., 8, 125-140.

Little, T. A., S. L. Baldwin, P. Q. Fitzgerald, and B. Monteleone (2007), Continental rifting and metamorphic core complex formation ahead of the Woodlark spreading ridge, D'Entrecasteaux Islands, Papua New Guinea, Tectonics, 26, TC1002, doi:10.1029/ 2005 TC001911.

Macdonald, K. C. (1982), Mid-ocean ridges: Fine scale tectonic, volcanic and hydrothermal processes within the plate boundary zone, Annu. Rev. Earth Planet. Sci., 10, 155-190, doi:10.1146/annurev.ea.10.050182.001103.

Martínez, F., B. Taylor, and A. M. Goodliffe (1999), Contrasting styles of seafloor spreading in the Woodlark Basin: Indications of rift-induced secondary mantle convection, J. Geophys. Res., 104(B6), 12,909-12,926, doi:10.1029/1999JB900068.

Massoth, G. J., E. T. Baker, R. A. Feely, J. E. Lupton, R. W. Collier, J. F. Gendron, K. K. Roe, S. M. Maenner, and J. A. Resing (1998), Manganese and iron in hydrothermal plumes resulting from the 1996 Gorda Ridge event, Deep Sea Res., Part II, 45(12), 2683-2712, doi:10.1016/S09670645(98)00089-7.

Mosher, S., and C. M. Symons (2008), Ridge reorientation mechanisms: Macquarie ridge complex, Australia-Pacific plate boundary, Geology, 36(2), 119-122, doi:10.1130/ G24236A.1.

Scheirer, D. S., E. T. Baker, and K. T. M. Johnson (1998), Detection of hydrothermal plumes along the Southeast Indian Ridge near the Amsterdam-St. Paul Plateau, Geophys. Res. Lett., 25(1), 97-100, doi:10.1029/97GL03443.

Searle, R. C., et al. (2010), Structure and development of an axial volcanic ridge: Mid-Atlantic Ridge, $45^{\circ} \mathrm{N}$, Earth Planet. Sci. Lett., 299(1-2), 228-241, doi:10.1016/j.epsl. 2010.09.003.

Smith, D. K., and J. R. Cann (1990), Hundreds of small volcanoes on the median valley floor of the Mid-Atlantic Ridge at 24-30 ${ }^{\circ} \mathrm{N}$, Nature, 348 , 152-155, doi:10.1038/348152a0.

Taylor, B., and P. Huchon (2002), Active continental extension in the western Woodlark Basin: A synthesis of Leg 180 results, Proc. Ocean Drill. Program Sci. Results, 180, 1-36.

Taylor, B., A. Goodliffe, F. Martinez, and R. Hey (1995), Continental rifting and initial sea-floor spreading in the woodlark basin, Nature, 374(6522), 534-537, doi:10.1038/374534a0.

Taylor, B., K. Kellmer, F. Martinez, and A. Goodliffe (1996), Sea-floor spreading in the Lau back-arc basin, Earth Planet. Sci. Lett., 144(1-2), 35-40, doi:10.1016/0012-821X(96)00148-3.

Taylor, B., A. M. Goodliffe, and F. Martinez (1999), How continents break up: Insights from Papua New Guinea, J. Geophys. Res., 104(B4), 7497-7512, doi:10.1029/1998JB900115.

Tregoning, P., et al. (1998), Estimation of current plate motions in Papua New Guinea from Global Positioning System observations, J. Geophys. Res., 103(B6), 12,181-12,203, doi:10.1029/ 97JB03676.

Walker, S. L., E. T. Baker, J. A. Resing, W. W. Chadwick Jr., G. T. Lebon, J. E. Lupton, and S. G. Merle (2008), Eruptionfed particle plumes and volcaniclastic deposits at a submarine volcano: NW Rota-1, Mariana Arc, J. Geophys. Res., 113, B08S11, doi:10.1029/2007JB005441.

Weissel, J. K., B. Taylor, and G. D. Karner (1982), The opening of the Woodlark Basin, subduction of the Woodlark spreading system and the evolution of northern Melanesia since Mid-Pliocene time, Tectonophysics, 87(1-4), 253-277. 